\title{
Influence of social networks on the purchase decisions of university students
}

\section{Influencia de las redes sociales sobre las decisiones de compra de estudiantes universitarios}

\author{
Lorena Estefania GutiérRez Flórez ${ }^{1}$ \\ Maria Isabel Correa Escobar ${ }^{1}$ \\ Andrés Henao Restrepo ${ }^{1}$ \\ Diana Arango-Botero ${ }^{2}$ \\ Alejandro Valencia-Arias ${ }^{2}$ \\ Universidad Nacional de Colombia (Colombia) \\ Instituto Tecnológico Metropolitano (Colombia)
}

Recibido el 5 de septiembre de 2015, aceptado el 20 de marzo de 2017

$\mathrm{N}^{\mathrm{o}}$ de clasificación JEL: M31, L81

DOI: $10.5295 / \mathrm{cdg} .150577 \mathrm{lj}$

\begin{abstract}
:
The emergence of social networks has not just had a great impact in the way companies promote their products and services, but also in the decision-making process of consumers regarding their purchases. Using the application and extension of the models proposed by Okazaki et al. (2012), the present study tries to understand the factors that motivate the use of social networks in the purchase decisions of young university students, for this a self-administered questionnaires were applied to 224 university students. Some limitations were found at the time of evaluating the adjustment of the model through a structural equations method, due to the number of indicators per construct. However, the results show that the proposed model presents a good adjustment. Therefore, it can be concluded that the study develops an appropriate approach to the knowledge of the factors that can influence university students, who intend to use social networks to buy, validating the conclusions drawn by Okazaki et al. (2012) in their study. At last, it is recommended for companies that wish to promote their products through social networks to look out for strategies that combine information transparency and stimulation of word-of-mouth communication among users, generating a larger impact on the purchase decisions of clients.
\end{abstract}

Keywords:

Trust, purchase decisions, information, marketing, social networks.

1 Department of Organization Engineering. Carrera 80 No 65-223. Postal code: 050034.(Colombia). legutierrezf@ unal.edu.co; maicorreaes@unal.edu.co; anhenaore@unal.edu.co

2 Departament of Management Sciences. Carrera 31 No 54-10. Postal code: 050013 (Colombia). dianaarangob@ itm.edu.co; jhoanyvalencia@itm.edu.co 


\section{Resumen:}

El auge de las redes sociales no solo ha tenido un alto impacto en la manera como las empresas promocionan sus productos y servicios, sino también en la toma de decisiones de los consumidores en cuanto a sus compras. Partiendo de la aplicación y extensión de uno de los modelos propuestos por Okazaki et al. (2012), este estudio busca entender los factores que motivan el uso de las redes sociales en las decisiones de compra de los jóvenes universitarios, para lo cual, se llevó a cabo la aplicación de cuestionarios auto-administrados a 224 estudiantes universitarios. Aunque a la hora evaluar el ajuste del modelo por medio de la metodología de ecuaciones estructurales se encontraron algunas limitaciones por el número de indicadores por constructo, los resultados señalan que el modelo propuesto presenta un buen ajuste, con lo cual se concluye que este estudio permite obtener una aproximación del conocimiento de esos factores que pueden influenciar la intención de uso de las redes sociales para comprar en los jóvenes universitarios; validando las conclusiones obtenidas por Okazaki, et al. (2012) en su trabajo. Por último, se recomienda a las empresas que deseen promocionar sus productos a través de las redes sociales, el buscar estrategias que incorporen transparencia en la información y estimulen el "voz-voz" entre los usuarios, generando así un mayor impacto en las decisiones de compra de los clientes.

\section{Palabras clave:}

Confianza, decisión de compra, información, mercadeo, redes sociales. 


\section{INTRODUCTION}

The growth of the Web 2.0 along with the advance and popularity of online social networks, have had a high impact in the way companies promote and commercialize their products and services (Bolotaeva and Cata 2010). Online communication has turned into a dominating channel that influences the purchase decisions of consumers, where social networks become a strong source of information to clients (Cheung et al. 2009, cited in Akar and Topçu 2011). The present study focuses on analyzing the different possibilities that companies have through the use of social networks to generate new marketing strategies, and examine the influence that these strategies have on the purchase intentions of university students.

Initially, a literature review is made on the emergence of social networks, its influence in the market and other determining factors of the social networks use in purchase decisions. Afterwards, a new model is proposed and tries to identify those factors that influence directly and indirectly the intensions of the social networks use to make a purchase, applying the model proposed by Okazaki et al. (2012) with their main hypothesis and later extending it by adding a new cause-effect relation based on exposed by the Theory of Reasoned Action (TRA). The method of structural equations is used to evaluate the adjustment of the model. Finally, conclusions and recommendations are made for companies that wish to use social networks for increasing their competitiveness in the market.

\section{LITERATURE REVIEW}

\subsection{Contextualization of Web 2.0, social media and the emergence of social networks}

Information and Communication Technologies (ICTs) have affected various dimensions of modern societies, modifying even economic, politic, social and cultural structures (Bran et al. 2017). Internet has changed how people work, communicate and live, and has become one of the most ideal mediums to generate interaction among users (Akar and Topçu 2011; Hoyos and Valencia 2012), allowing a faster, a more synchronized and opportune exchange and availability of information (Hsu et al. 2007), generating an invaluable management system tool for knowledge creation, communications and marketing research (Valencia et al. 2013).

The term Web 2.0 is commonly used to define technologies and applications developed in the Internet. Also, along with the advance and popularity of online social networks, have had a high impact in the way companies and consumers commercialize their products and services (Bolotaeva and Cata 2010).

The emergence of social networks have attracted millions of users that can share pictures, videos, opinions and experiences with other users since their first launch in 1997 (Maurer and Wiegmann 2011) and given the possibility of acquiring information of products from companies (Mangold and Faulds 2009), a good example is proposed by Quinton and Harridge (2010, cited in Soares et al. 2012, p.46) of the remarkable increase in the participation of users in the Web 2.0 emerging content. 
In a similar way, Cheung et al. (2009, cited in Akar and Topçu 2011) suggest that online communication has become a dominant channel that influences the purchase decisions of consumers, being a valuable source of information to clients. These networks open the possibility to establish communities that provide the means to access and share publicity, adds and novelties that brands promote, with the purpose of exploiting their advertising capacities and positioning their brands in the target market (Alvarado 2012).

\subsection{Importance and influence of social networks in marketing}

According to Pookulangara and Koesler (2011), social networks have become one of the most important tools to identify and create marketing strategies, given that their use has generated big possibilities and opportunities to learn about consumers' needs, and consequently answer opportunely, proactively and creatively to clients. Besides, each network helps to understand the client, plainly identify their biggest unsatisfied needs, answer their demands, and give the group value (Cheung and Lee 2010).

Moreover, one of the main challenges of businesses nowadays is to identify the target audience they must address, and also to determine the proper timing to present their marketing strategy (Hill et al. 2006). A series of efficient tools arise from this concern, the first tool is the Word-of-Mouth (WOM) technique. According to an investigation made by Kalpaklioglu and Toros (2011), around $78 \%$ of consumers in 47 countries trust on the recommendations of other consumers. This is why sellers have increasingly become more interested in new techniques like the Word-of-Mouth (WOM) than in conventional advertising techniques.

Among other techniques, there are product samples, which are distributed by companies through social networks to their potential consumers, using digital bonuses for physical products and periods of time for services (Nooy et al. 2011, cited in Schlereth et al. 2013). Nonetheless, the success of this strategy depends on an adequate selection of consumers to guarantee a widespread and fast broadcast of the information.

Taking the above into account, Kunz and Hackworth (2011) found that consumers today have turned to look for information about new products, sales and discounts by following brands on social networks. On one hand, companies have the opportunity to create cheaper and friendlier campaigns for their products. On the other hand, there are certain weaknesses about social networks and businesses, such as aggressive advertising, invasion of privacy, and legal issues (Bolotaeva and Cata 2010).

Likewise, Ontario (2008, cited in Akar and Topçu 2011) exposes how companies use social media to increase the corporation's visibility, presenting their products and services, in order to interact with members of the community, thus an exchange of ideas and information is generated. Additionally, according to Tanuri (2010), companies are starting to understand the use of social media as a component to develop their market research, marketing strategy, the monitoring of their consumers' feelings, public relations, customer management, and also using it as an advertising channel to create assertive campaigns to successfully reach their target audience. (Tanuri 2010, cited in Akar and Topçu 2011). 
Complementing the above, Cocheo (2009, cited in Kunz and Hackworth 2011) assures that consumers' response is more favorable because they have control over their opinions and decisions. The possibility to generate, edit, and share online information about companies, products and services, makes consumers more confident towards other users' opinions by considering them more objective and trustworthy information than the messages generated by the companies. Therefore, opinions among peers become an important influence in purchase behavior (Akar and Topçu 2011). Particularly, a study made by DEI Worldwide ${ }^{3}$ about the consumers' points of view toward social media (Akar and Topçu 2011), shows how consumers that interact with social networks engage better purchase decisions than the ones that do not. Furthermore, Miller and Lammas (2010), based on the same study, suggested that $70 \%$ of consumers visit social networks to get information and $49 \%$ of these clients take their purchase decisions based on the information collected there.

All of the above can be summarized in a new trend called Shopping 2.0 or social shopping, in which social networks try to become a place to consult and purchase, where users can answer all the questions they have concerning the products they are interested in, they can read and share comments, and of course, buy the products and services offered through social networks (Alvarado 2012).

\subsection{Determining factors of the use of social networks in purchase decisions}

Brymer (2009, cited in Wang and Chang 2013) states that merchandising methods are changing remarkably nowadays business interaction and the most valuable information today about the consumers' decision-making is linked to the trust that social media members generate, while experts, authorities, mass media and mass advertising have consequently lost strength. In this way, the consumers' participation in social networks is motivated by different factors. Dholakia et al. (2004) propose in their study the following five factors: i) intentional value, the perceived satisfaction following the success of a predetermined purpose; ii) self-discovery, given that interactions can help define each person's preferences, likes, dislikes and values (McKenna and Bargh 1999, cited in Dholakia et al. 2004); iii) interpersonal connectivity, because of the social benefits given by establishing relationships with other people (social support, friendship, intimacy) (Dholakia et al. 2004); iv) social recognition, that is a strong motivation to certain consumers that consider it important to win the acceptance and approval of others (Baumeister 1998, cited in Dholakia et al. 2004); and v) value of entertainment, which comes from the fun and relaxation that arises from sharing with other members of the Web (McKenna and Bargh 1999, cited in Dholakia et al. 2004).

Another study shows that virtual communities, despite being flexible and based upon a wide range of cultural interests and social affiliations (Bermudez et al.2017), compared with traditional organizations are fragile because they do not guarantee what is expected (Hsu et al. 2007). The effects on the decision-making are based

3 DEI Worldwide is a leading social media marketing agency with specialties in conversational outreach, integrated strategies, market research, viral content creation and application development. 
on the strength of the created bonds, homophily, source credibility, and also on the impact over personalities of virtual community members (self-esteem, leadership, online behavior) (Acar and Polonsky 2007). Additionally, Soares et al. (2012) investigate whether social interactions among social network users (trust and social relationships) have a positive impact in a series of marketing interactions (information broadcast, WOM, and attitude toward the advertisement). The present study was made in 150 university students between 18 and 35 years old, concluding that trust is an important human factor that stimulates the tendency to give and receive information within a social network and that reduces uncertainties and simplifies decision-making. Likewise, trust has a positive impact on WOM, the exchange of information and its broadcast amongst consumers (Soares et al. 2012).

Furthermore, a study applied to bachelor students of eight different faculties of the University of Afyon Kocatepe between 18 and 24 years old to determine the influencing factors in the attitudes of consumers towards social media marketing, presents an analysis of 7 factors: responsive attitudes toward merchandising through mass media, use of mass media, knowledge of social media, level of affectation by social media, participation in any social network, prospective over social networks, and the fear of marketing related to social media. The study concluded that the degree of information processing, comparisons, and purchase behavior is affected by the previously acquired knowledge from the opinions of other consumers by the digital experience. It was also concluded that experience in social media generates a better attitude while interacting in the Web, and that consumer attitudes positively affect purchase through the previous gathering of information and WOM. It can be assumed from the above that people are looking for more products and services online before making a purchase, being social networks a means that allow customers to reach products, services and brands related to their own experiences (Akar and Topçu 2011).

\section{MODEL OF OKAZAKI ET AL. (2012)}

In accordance with the literature review made above, the proposed work regarding social networks have been oriented towards its influence in marketing strategies and interactions related to advertising and information spreading. The model proposed by Okazaki et al. (2012), which understand the basic mechanism of the social influence that takes place in the usage of social networks, it will be used to identify the factors that can affect the intention to use social networks to make a purchase.

The model proposed by Okazaki et al. (2012) derives from the brand community model designed by Algesherimer et al. (2005), which is based on the literature about brand communities (Mcalexander, et al. 2002; Muniz and O'guinn 2001), social identification (Bhattacharya and Sen 2003), and interactions among consumers (Dholakia et al. 2004). The definition for each construct is structured in the Table 1. 
Table 1

Constructs of the model of Okazaki et al. (2012)

\begin{tabular}{|l|l|}
\hline \multicolumn{1}{|c|}{ Construct } & \multicolumn{1}{c|}{ Definition } \\
\hline $\begin{array}{l}\text { Identification with the } \\
\text { social network (IWSN) }\end{array}$ & $\begin{array}{l}\text { Refers to the strength of the relationship between the user and the } \\
\text { social network, as well as the convergence between psychological } \\
\text { attributes of the users and the website's content. }\end{array}$ \\
\hline $\begin{array}{l}\text { Commitment with the } \\
\text { social network (CWSN) }\end{array}$ & $\begin{array}{l}\text { It refers to the positive influences of the personal identification with a } \\
\text { social network, which are defined as the intrinsic motivations of inte- } \\
\text { racting and cooperating with members of the social network. }\end{array}$ \\
\hline $\begin{array}{l}\text { Attachment degree } \\
\text { (AD) }\end{array}$ & $\begin{array}{l}\text { It is the intensity of the interactive and personalized relationship bet- } \\
\text { ween an individual and a website. }\end{array}$ \\
\hline $\begin{array}{l}\text { Perceived usefulness } \\
\text { (PU) }\end{array}$ & $\begin{array}{l}\text { It is the value obtained by achieving a predetermined instrumental pur- } \\
\text { pose and by the exchange of information through participation in the } \\
\text { virtual community. This construct combines the value of the informa- } \\
\text { tion and the instrumental value of the means of communication. }\end{array}$ \\
\hline Social recognition (SR) & $\begin{array}{l}\text { Obtained social benefits, such as social support, friendship and } \\
\text { intimacy that arise by establishing and maintaining contact with other } \\
\text { people. }\end{array}$ \\
\hline Entertainment (E) & It is the motivation for online media use. \\
\hline Social pressure (SP) & $\begin{array}{l}\text { It is an important element of the attitude in the theoretical formula- } \\
\text { tions of behavior that can consist in public conformity or in the private } \\
\text { acceptance of rules. When public conformity is not accompanied by } \\
\text { a complete acceptance at a private level, the person suffers from peer } \\
\text { pressure, which plays a significant influence in his or her behavior. }\end{array}$ \\
\hline $\begin{array}{l}\text { Electronic Word-of- } \\
\text { Mouth (e-WOM) }\end{array}$ & $\begin{array}{l}\text { Refers to the exchange of information and interaction among users } \\
\text { where debates about personal opinions on certain subjects occur. }\end{array}$ \\
\hline $\begin{array}{l}\text { Intention to search } \\
\text { information (ISI) }\end{array}$ & $\begin{array}{l}\text { Refers to the behavior towards a brand and the search of information } \\
\text { about a brand. }\end{array}$ \\
\hline
\end{tabular}

Source: Okazaki et al. (2012).

The model is made up of three blocks. The first block is based on the main constructs of the model proposed by Algesherimer et al. (2005). The two remaining blocks constitute precisely the extension suggested by Okazaki et al., where antecedents are derationed on the topic of brand identification (degree of identification, entertainment in the Web, social recognition and Web's perceived usefulness) and the commitment with the network consequences (Word-of-Mouth and behavior toward the brand) illustrated in Figure 1. 
Figure 1

Model by Okazaki et al. (2012)

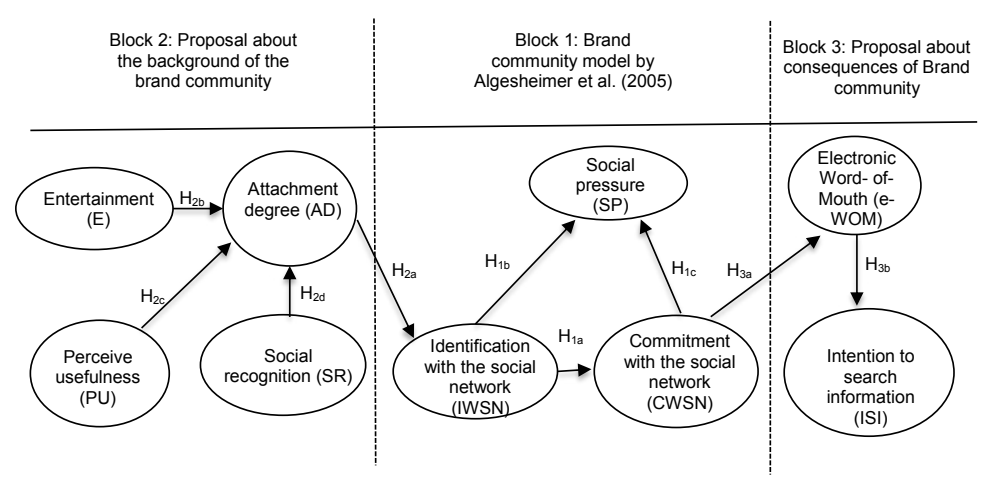

Source: Okazaki et al. (2012).

The constructs and the relations among them compose the first block. These constructs are considered in the brand community model of Algesherimer et al. (2005), and are adapted by the model of Okazaki et al. (2012) with the purpose of identifying the way users react to brand advertising through social networks, carried out by companies. The hypotheses that constitute the first block are:

H1a: Identification with the social network has a significant positive effect on the commitment of users with the social network

H1b: Identification with the social network has a significant negative effect on social pressure. H1c: The commitment to the social network has a significant positive effect on social pressure.

The second block includes the antecedents of the identification with the social network suggested by Okazaki et al. (2012) with the purpose of obtaining a different perspective of social networks from electronic Word-of-Mouth (e-WOM). To achieve this purpose, a study by Brown et al. (2007) that explores e-WOM communication on online communities was considered. Three main variables are observed in this study: the attachment degree, the identification and credibility of the source, and the influence over the e-WOM exchange of information. The first two variables were considered by the model of Okazaki et al., in which the attachment degree can be defined as "the intensity of the interactive and personalized relationship between and individual and the website", and the identification as "the convergence between psychological attributes of the users and the website's content" (Okazaki et al. 2012, p. 35). The hypotheses considered in the second block are:

H2a: Attachment degree has a significant positive effect on the identification with the social network.

H2b: Entertainment has a significant positive effect on the attachment degree.

H2c: Perceived usefulness has a significant positive effect on the attachment degree.

$\mathrm{H} 2 \mathrm{~d}$ : Social recognition has a significant positive effect on the attachment degree. 
Okazaki et al. add two more variables to the third block: e-WOM and the intention to search information, where the first one affects the second given that communications through e-WOM affects the intentional behavior toward the brand. Furthermore, commitment with the social network influences the e-WOM, because when the users are committed to a brand, it is more probable that they would transmit information they think interesting to other users. Then, the following hypotheses are suggested:

H3a: Commitment with the social network has a significant positive effect on the e-WOM. $\mathrm{H} 3 \mathrm{~b}$ : The e-WOM has a significant positive effect on the intention to search information.

\section{RESEARCH METHODOLOGY}

Given that the purpose of this study is to analyze the influence of contents in social networks in the purchase decisions of university students, one of the models contemplated by Okazaki et al. (2012) was used as reference because it presents well-defined constructs and relationships between them, aiming to comprehend the basic mechanism of social influence that acts in social networks. Just as Okazaki acknowledges and extends the brand community model by Algesheimer et al. (2005), contrasting the proposed relations in the theoretical model and looking for validation of the influence of social networks, the present study seeks to adapt this model to the understanding the factors and variables that motivate the use of social networks in the decision-making processes when a user is making a purchase.

To reach this aim, a quantitative methodological design was carried out through self-administered questionnaire, which were applied in physical format to 224 undergraduate students from the Engineering Department of the Universidad Nacional de Colombia, Medellín.

According to ComScore (2013), the highest percentage of Internet visitors in Colombia corresponds to people between $15-24$ years old, with a value of $42.9 \%$, followed by $26.8 \%$ for the age group between 25 and 34 years, $16.1 \%$ for those aged between $35-44$ and $14.2 \%$ for those over 45 . All these people, according to the same source, consume their longest connection time in social media with an average of 5.76 hours-person per month followed by 3.33 hours for entertainment and 2.88 hours on average for services. This justifies the selection of the sample of university students, who were selected through non-probabilistic sampling by criterion, to answer a total of 30 questions, with the intention of knowing their perceptions in a Likert scale of 5 points, in the following areas: i) Advertising of a brand through social networks (brand community model by Algesherimer et al. 2005, which includes social pressure, identification with the social network and commitment to the social network); ii) Brand identification (entertainment, attachment degree, perceived usefulness of the network and social recognition) and iii) Commitment to the social network (electronic Word-of-mouth and behavior towards the brand).

In order to validate the proposed model, its constructs and the relationships between them, convergent and discriminant validations were made, in which some statistics such as the Bartlett's sphericity test and the KMO measure were used and analyzed, corresponding to the evaluation of the Cronbach's alpha, to verify the reliability of the instrument's 
internal consistency, which assumes that different items measure the same construct and are highly correlated. Finally, the methodology of structural equations was used to evaluate the adjustment of the model to the data, since it is a reliable methodology for this type of intention models (Valencia et al. 2016).

\section{PROPOSED MODEL FOR THE INTENTION TO USE SOCIAL NETWORKS TO MAKE A PURCHASE}

The model proposed in this article, as already discussed above, is based on the model presented by Okazaki et al., considering the same three blocks and most of the relations included in the model.

According to Dholakia et al. (2004), the participation of consumers in social networks is motivated by several factors, including the intentional value, recognition, and value of entertainment. Hence, the same three hypotheses are taken from the second block that Okazaki contemplated for the model proposed in the present article:

H1: Entertainment has a significant positive effect on the attachment degree.

$\mathrm{H} 2$ : Perceived usefulness has a significant positive effect on the attachment degree.

H3: Social recognition has a significant positive effect on the attachment degree.

Communication and marketing have entered a new era characterized by the interactivity provided by modern technologies. The protagonism acquired by the user, is framed in a situation of market liberalization, increased competition and the power of the Internet in communications. In this way, consumers have become an active part of commercial communication, selecting or ignoring the messages that interest them, and interacting or creating new content thanks to the possibilities offered by the Internet (Arcos et al. 2014). Likewise, the growing development of Web 2.0 technologies and social networks has generated a wide range of possibilities for both companies and consumers. These possibilities increase due to the great reception they have had from online users. In addition, companies seek to create better experiences for consumers in order to increase sales, create customer loyalty and a stronger brand positioning (Gatautis 2008, Vitkauskaite 2011, cited in Gatautis and Kazakevičiūtè 2012; Cartagena et al. 2017).

This interactivity of online consumers was contemplated in the first block of the model proposed by Okazaki et al., when considering the constructs of the brand community model of Algesherimer et al. (2005). As the objective of the present article is to try to identify the factors that influence the intention to use social networks to make a purchase, the proposed model will adopt the same three hypotheses:

H4: Identification with the social network has a significant negative effect on social pressure. H5: Identification with the social network has a significant positive effect on the commitment with the social network.

H6: Commitment with the social network has a significant positive effect on social pressure.

In addition to the hypotheses proposed by Okazaki et al. (2012) for this first block, a new hypothesis will be proposed, which is extracted from the Theory of Reasoned Action (TRA), in which according to Fishbein and Ajzen (1975) and Ajzen and Fishbein (1980), 
one of the factors that lead an individual to perform certain behavior is the subjective norm, which is based on normative beliefs or social factor defined by specific social contexts (Valencia et al. 2014). Other authors such as Davis et al. (1989) argue that the subjective norm is determined by normative beliefs or individual perceptions regarding the influence of external groups composed of individuals that are important to them, and by individual motivations to follow a particular social norm.

The influence of the external groups of which the TRA speaks about, in the context of the intention to use social networks to make a purchase, can be seen as a kind of social pressure to carry out such behavior, giving way to the next hypothesis, which is not considered in the model proposed by Okazaki:

H7: Social pressure has a significant positive effect on the intention to use a social network to make a purchase.

Smith et al. (2007) and Akar and Topçu (2011) claim that consumers rely on the recommendations of other consumers, and that is why sellers increasingly use tools such as WOM. These same authors assert that the information of close consumers is perceived as more reliable, impartial, and generates more credibility than the persuasive information obtained in the publicity controlled by the companies.

Given the importance of the WOM and the information received by the consumers from the people close to them, the third block will establish the same two hypotheses contemplated in the model of Okazaki et al., considering "intention to use social networks to make a purchase" (variable) instead of "intention to search information".

H8: Commitment to the social network has a significant positive effect on electronic wordof-mouth communications.

H9: The e-WOM has a significant positive effect on the intention to use a social network to make a purchase.

Communication over the Internet has ceased to be unidirectional to become two-way communication. That is, the information is transmitted from the Web to the user and from the user to the Web. Among the tools that allow such interaction are: wikis, podcasts, tags, social networks, videos, among others. All of the above, converges to user-created content that has changed not only what the Web contains, but also how it works (Akar and Topçu 2011).

This interaction between the Web and the user will be considered in the construct "attachment degree", since according to Okazaki et al., this defines the intensity of the relationship between an individual and a website, so it is natural to think that the more intense the relationship, greater the interaction of the former with the latter will be for different purposes, i.e. the purchase. Hence the construction of hypothesis 10 , which was not contemplated by the model of Okazaki et al., and which relates to the attachment degree with the intention to use the social network to make a purchase.

H10: The attachment degree has a significant positive effect on the intention to use a social network to make a purchase.

Regarding the theoretical considerations discussed above and the adaptations and extensions made from the model of Okazaki et al., the model proposed in the present article is illustrated in Figure 2. 
Figure 2

\section{Proposed model for the present article}

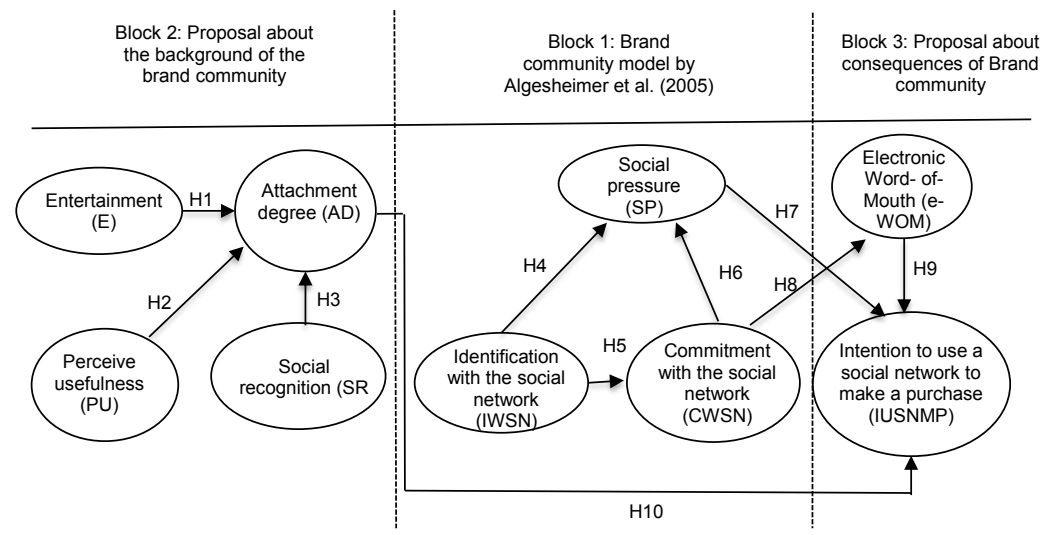

Source: Adaptation of Okazaki et al. (2012).

\section{ANALYSIS OF RESULTS}

\subsection{Validity of the model}

For the validation of the adapted and extended model from the one proposed by Okazaki et al. (2012) the SPSS ${ }^{4}$ software was used, with which convergent and discriminat type validations were performed. These validations allow identifying, among other things, those items that correlate more with the set of items that are measuring the construct. According to Campbell and Fiske (1959, cited in Martínez-García and Martínez-Caro 2009) for the measures of a given model to be valid, there must exist a high correlation between measures of the same construct (convergent validity), and that correlation in regard to measures of other constructs, must be greater (discriminant validity).

\section{A. Convergent Validity}

In order to achieve the union or convergence of the model, after finding the standardized factor loads of all the initially considered indicators, it was necessary to eliminate those corresponding to CWSN1, SP1, E3, E4, AD1, IUSVMP1, SR2 and PU1, since these reduced the value of the average obtained from the loads of the indicators on each factor, which according to the literature review, should be higher than 0.7 for all constructs (Hair et al. 2001), as shown in Table 2, where the indicators mentioned above were effectively eliminated.

4 Statistical Package for the Social Sciences software package. 
Table 2

Convergent validity refined from standardized factor loads

\begin{tabular}{|c|c|c|c|}
\hline Construct & Item & $\begin{array}{c}\text { Standarized factor } \\
\text { loads }\end{array}$ & $\begin{array}{c}\text { Average of standarized } \\
\text { factor loads }\end{array}$ \\
\hline \multirow{2}{*}{$\begin{array}{c}\text { Commitment with the social } \\
\text { network }\end{array}$} & CWSN2 & 0.919 & \multirow{2}{*}{0.919} \\
\hline & CWSN3 & 0.919 & \\
\hline \multirow{2}{*}{ electronic Word-of-Mouth } & e-WOM1 & 0.871 & \multirow{2}{*}{0.871} \\
\hline & e-WOM2 & 0.871 & \\
\hline \multirow{2}{*}{ Entertainment } & E1 & 0.819 & \multirow{2}{*}{0.819} \\
\hline & E2 & 0.819 & \\
\hline \multirow{3}{*}{ Attachment degree } & $\mathrm{AD} 2$ & 0.657 & \multirow{3}{*}{0.726} \\
\hline & AD3 & 0.850 & \\
\hline & $\mathrm{AD} 4$ & 0.671 & \\
\hline \multirow{2}{*}{$\begin{array}{l}\text { Identification with the social } \\
\text { network }\end{array}$} & IWSN1 & 0.901 & \multirow{2}{*}{0.901} \\
\hline & IWSN2 & 0.901 & \\
\hline \multirow{3}{*}{$\begin{array}{l}\text { Intetion to use social network } \\
\text { to make a purchase }\end{array}$} & IUSNMP2 & 0.639 & \multirow{3}{*}{0.743} \\
\hline & IUSNMP3 & 0.764 & \\
\hline & IUSNMP4 & 0.826 & \\
\hline \multirow{3}{*}{ Social pressure } & $\mathrm{SP} 2$ & 0.874 & \multirow{3}{*}{0.900} \\
\hline & SP3 & 0.917 & \\
\hline & SP4 & 0.909 & \\
\hline \multirow{2}{*}{ Social recognition } & SR1 & 0.718 & \multirow{2}{*}{0.707} \\
\hline & SR3 & 0.697 & \\
\hline \multirow{3}{*}{ Perceived usefulness } & PU2 & 0.811 & \multirow{3}{*}{0.750} \\
\hline & PU3 & 0.832 & \\
\hline & PU4 & 0.606 & \\
\hline
\end{tabular}

Source: Own elaboration.

Afterwards, the Bartlett's sphericity test and the KMO measure are presented in Table 3 , since they are the statistics corresponding to the study of the adequacy of the model to the sample. The first referred statistic is a test that is used to check the hypothesis that the correlation matrix obtained is not an identity matrix, meaning there are significant inter-correlations among the variables that justify the factorial analysis (De la Fuente and 
Justicia 2003). Its $p$ value must be lower than the critical levels 0.05 or 0.01 , because if the critical level is greater than 0.05 , the null hypothesis of sphericity cannot be rejected and, consequently, it cannot be assured that the factorial model is adequate to explain the data (Uriel and Manzano 2002). Given that the proposed model presents Bartlett's values equal to zero, it can be affirmed that there are significant correlations between the variables.

Moreover, the value of the Kaiser-Meyer-Olkin (KMO) sampling adequacy measure is defined as an index that compares the magnitudes of the correlation coefficients observed with the magnitudes of the partial correlation coefficients, and their value is between 0 and 1. This value is used as a measure of sample adequacy, knowing that the low values in this index discourage the application of this analysis (De la Fuente and Justicia 2003). Kaiser (1974) characterizes these values on a scale that considers KMO measures closer to 0.90 as marvelous, to 0.80 as meritorious, to 0.70 as medium, to 0.60 as mediocre, and below 0.50 as unacceptable (Lévy et al. 2006).

Table 3

Convergent KMO validation and Bartlett's sphericity test

\begin{tabular}{|l|l|l|l|}
\hline \multicolumn{1}{|c|}{ Factor } & $\begin{array}{c}\text { KMO } \\
\text { value } \\
\text { Commitment with the social network }\end{array}$ & $\begin{array}{c}\text { Barlett } \\
\text { value }\end{array}$ & $\begin{array}{c}\text { Fulfilled } \\
\text { criteria }\end{array}$ \\
Electronic Word-of-Mouth & 0.500 & 0.00 & Yes \\
Entertainment & 0.500 & 0.00 & Yes \\
Attachment degree & 0.500 & 0.00 & Yes \\
Intention to use social network to make a purchase & 0.500 & 0.00 & Yes \\
\cline { 2 - 4 } Identification with the social network & 0.590 & 0.00 & Yes \\
\hline Social pressure & 0.733 & 0.00 & Yes \\
\hline Social recognition & 0.500 & 0.00 & Yes \\
\hline Perceived usefulness & 0.590 & 0.00 & Yes \\
\hline
\end{tabular}

Source: Own elaboration.

Table 3 shows the coefficients provided by the SPSS software for each factor meet the mentioned criteria, which indicates that it is feasible to perform the data reduction technique, and thus clarify the reality on the factors that influence the perceptions of university students to use social networks as a means of purchasing different goods.

\section{B. Discriminant Validity}

Discriminant validity is one of the common criteria for evaluating latent variables in social sciences. It is stated in this phase that for measures to be valid, those of the same construct must correlate highly among them, and that correlation must be greater than that existing among the measures proposed for another construct (Campbell and Fiske 1959, cited in Martínez-García and Martínez-Caro 2009). In the present research, a discriminant 
validity analysis was performed, by checking that the confidence interval in the correlation estimated between each pair of factors did not contain the value of 1 (Anderson and Gerbing 1988). Table 4 shows that all cases satisfy this criterion.

Table 4

Discriminant validity of the measurement model

\begin{tabular}{|c|c|c|c|c|c|c|c|c|c|}
\hline & CWSN & e-WOM & E & $\mathrm{AD}$ & IWSN & IUSNMP & SP & SR & $\mathrm{PU}$ \\
\hline CWSN & $\ldots$ & & & & & & & & \\
\hline e-WOM & {$[0,133 ; 0,396]$} & $\ldots$ & & & & & & & \\
\hline $\mathrm{E}$ & {$[-0,132 ; 0,122]$} & {$[-0,041 ; 0,226]$} & $\ldots$ & & & & & & \\
\hline $\mathrm{AD}$ & {$[-0,075 ; 0,174]$} & {$[-0,037 ; 0,236]$} & {$[-0,061 ; 0,216]$} & $\ldots$ & & & & & \\
\hline IWSN & {$[0,074 ; 0,301]$} & {$[-0,024 ; 0,255]$} & {$[-0,116 ; 0,142]$} & {$[-0,024 ; 0,243]$} & $\ldots$ & & & & \\
\hline IUSNMP & {$[-0,060 ; 0,202]$} & {$[-0,055 ; 0,207]$} & {$[-0,096 ; 0,180]$} & {$[0,121 ; 0,377]$} & {$[0,113 ; 0,358]$} & $\ldots$ & & & \\
\hline SP & {$[-0,030 ; 0,240]$} & {$[0,092 ; 0,342]$} & {$[-0,062 ; 0,192]$} & {$[0,121 ; 0,362]$} & {$[0,009 ; 0,270]$} & {$[0,448 ; 0,655]$} & $\ldots$ & & \\
\hline SR & {$[0,101 ; 0,357]$} & {$[-0,033 ; 0,239]$} & {$[0,107 ; 0,368]$} & {$[-0,124 ; 0,142]$} & {$[0,068 ; 0,322]$} & {$[-0,063 ; 0,190]$} & {$[-0,002 ; 0,244]$} & $\ldots$ & \\
\hline PU & {$[0,013 ; 0,252]$} & {$[0,085 ; 0,339]$} & {$[0,186 ; 0,437]$} & {$[-0,015 ; 0,255]$} & {$[0,100 ; 0,362]$} & {$[0,031 ; 0,305]$} & {$[0,210 ; 0,441]$} & {$[0,159 ; 0,399]$} & $\ldots$ \\
\hline
\end{tabular}

Source: Own elaboration.

It is verified that the instrument used measures in a high degree what it intends to measure. The reliability of the internal consistency of the instrument will be estimated using the Cronbach's alpha, since it is a reliable tool in which the items (Likert's scale) are assumed to measure the same construct and are highly correlated (Welch and Comer 1988). The internal consistency of the items is greater if the value of Cronbach's alpha is closer to 1 , since the test reaches positive values between 0 and 1 , where 0 indicates total absence of internal consistency, and 1 indicates total redundancy between items.

George and Mallery (2003) suggest the following recommendations to evaluate Cronbach's alpha coefficients: Coefficient alpha $>0.9$ is excellent, Coefficient alpha $>0.8$ is good, Coefficient alpha $>0.7$ is acceptable, Coefficient alpha $>0.6$ is questionable, Coefficient alpha $>0.5$ is poor, and Coefficient alpha $<0.5$ is unacceptable. However, in the early phases of the research a reliability value of 0.6 or 0.5 may be sufficient (Nunnally 1967, cited in Frías-Navarro 2013).

As shown in Table 5, the measurement instrument seems to have a high reliability of the internal consistency of the measurement scale, since the Cronbach's alpha of the analyzed constructs is among the range of values recommended and all factors are considered within the values recommended by George and Mallery (2003).

Table 5

Reliability index - Cronbach's Alpha

\begin{tabular}{|l|l|}
\hline Factor & Cronbach's alpha \\
\hline Commitment with the social network & 0.921 \\
\hline electronic Word-of-Mouth & 0.878 \\
\hline Entertainment & 0.828 \\
\hline
\end{tabular}




\begin{tabular}{|l|l|}
\hline Attachment degree & 0.774 \\
\hline Intention to use social network to make a purchase & 0.915 \\
\hline Identification to the social network & 0.781 \\
\hline Social pressure & 0.929 \\
\hline Social recognition & 0.771 \\
\hline Perceived utility & 0.794 \\
\hline
\end{tabular}

Source: Own elaboration.

The previous results show the existence of a sustainable factorial model for the analysis, based on the perceptions of university students on the use of social networks as a means to purchase different goods. The presence of convergent validity and discriminant validity within the instrument, together with an acceptable reliability, confirms that the instrument evaluates fundamental variables that directly or indirectly influence the ideas, expectations, and motivations in the use of social networks by university students.

\section{Model Adjustment}

At this point, the proposed structural model was estimated (Figure 3) to evaluate the intentions of social networks usage for purchase purposes. Various hypotheses were collected and its suitability evaluated, by recognizing its adjustment or not to the model proposed in this paper.

Figure 3

\section{Proposed model of structural equations}

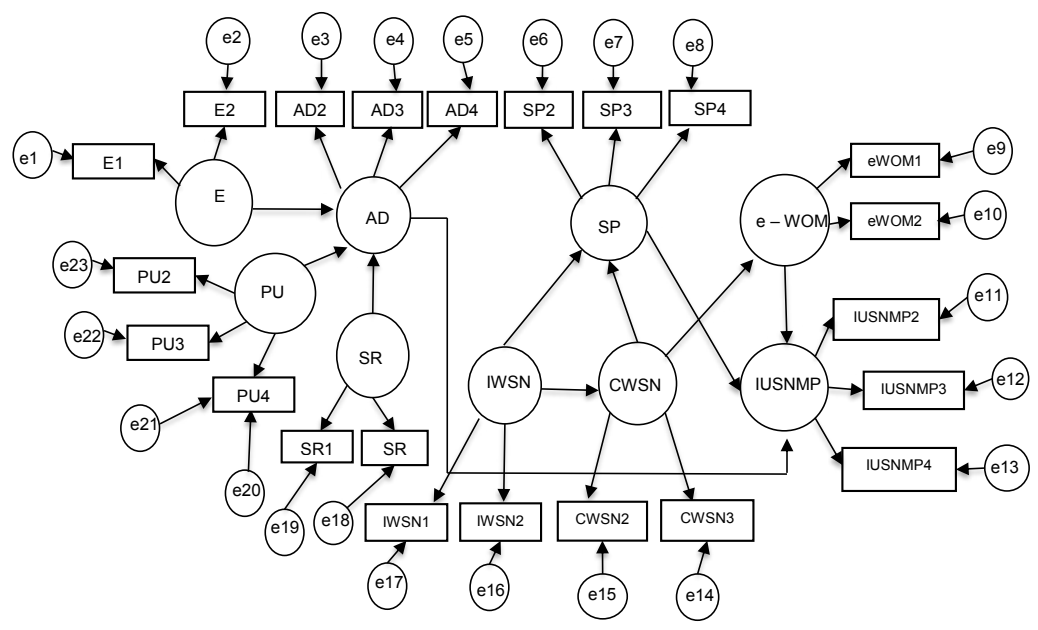

Source: Own elaboration.

Before carrying out the global evaluation of the model and determining the degree of adjustment in relation to the collected data, a confirmatory factor analysis (CFA) was 
performed for each of the constructs (Ranaweera 2016). Some examples of the use of such analysis for the of constructs' validation and evaluation of model factor structures can be found in Bryant et al. (2016), Pavia et al. (2016), Mahler et al. (2016).

It was possible to identify the degree which the indicators reflected the construct with the CFA, through the chi-square test and the following indexes: CFI, TLI, RMSEA and SRMR. The results are presented in Table 6.

Table 6

Chi-square test and construct fit indexes

\begin{tabular}{|l|l|l|l|l|l|}
\hline Construct & \multicolumn{1}{|c|}{ p-value } & \multicolumn{1}{c|}{ CFI } & \multicolumn{1}{c|}{ TLI } & \multicolumn{1}{c|}{ RMSEA } & \multicolumn{1}{c|}{ SRMR } \\
\hline PU & 0.649 & 1 & 1.026 & 0 & 0.018 \\
\hline AD & 0.218 & 0.993 & 0.978 & 0.048 & 0.051 \\
\hline SP & 0.59 & 1 & 1.004 & 0 & 0.061 \\
\hline IUSNMP & 0.847 & 1 & 1.038 & 0 & 0.009 \\
\hline
\end{tabular}

Source: Own elaboration.

Table 6 only presents the results for four of the nine constructs, and was obtained after a preliminary analysis. After determining the initially proposed model, it was required the following correlations between the residuals of indicators: PU2 and PU3, AD2 and AD3, AD3 and AD4, SP2 and SP3, IUSNMP2 and IUSNMP3, IUSNMP3 and IUSNMP4. The modified model is shown in Figure 4. The other five constructs were not analyzed, since within the limitations of the study stands out the fact that most of the constructs were originally associated with 3 or less indicators. At the moment of analyzing the factorial loads and eliminating those that did not contribute to the global average to exceed 0.7 , these five constructs were left with only two indicators, which imposes many constraints on the model and does not allow to considerate the presence of correlated errors (Kenny et al. 1998), making it difficult to evaluate the overall model adjustment.

Figure 4

\section{Modified model of structural equations}

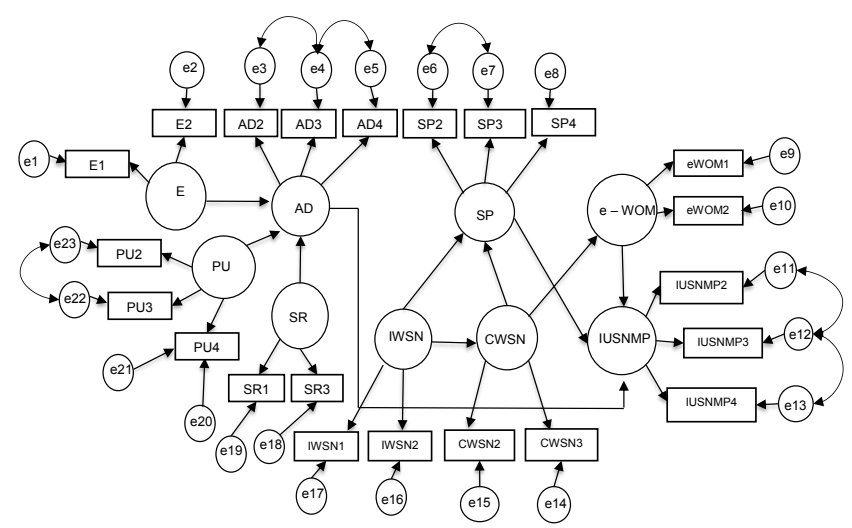

Source: Own elaboration. 
As can be seen in Table 6, the p-values of the chi-square test largely exceed the level of significance of 0.05 , so it can be concluded that there is a good fit in each of the constructs.

It is worth to mention at this point that, like any statistical test, chi-square is sensitive to the size of the sample (Hox and Bechger 1998). Therefore, the adjustment assessment is also supported by other indexes indicating a good fit if they are above 0.9 , for the case of IFC and TLI (Hair et al. 2001) and below 0.08 and 0.06 for SRMR and RMSEA indices respectively ( $\mathrm{Hu}$ and Bentler 1999). As the indices presented in Table 6 are within those reference values, it can be concluded that the fit between the modified model and the observed data is relatively good.

After modifying the initially proposed model by including some correlations between the residuals of some indicators, as indicated by the CFA, we proceeded with the analysis of the global model through the implementation of the methodology of structural equations, which was achieved with the Lavaan package of the software R. From such adjustment the $p$-value was obtained through the chi-square test and the values of the indices presented in Table 7 were obtained from this adjustment. Although the $p$-value seems to indicate that there is no good fit of the overall model, it has been previously indicated that the chi-square test is sensitive to the sample size, and as the other considered indices evidence that fit is good. It can be concluded that this model serves as a basis to understand the factors that have some influence, either directly or indirectly on the intentional use of social networks to make a purchase.

Table 7

Chi-square test and construct fit indexes

\begin{tabular}{|l|c|c|c|c|c|}
\hline & p-value & CFI & TLI & RMSEA & SRMR \\
\hline Global model & 0.0 & 0.935 & 0.919 & 0.048 & 0.076 \\
\hline
\end{tabular}

Source: Own elaboration.

\section{CONCLUSIONS AND IMPLICATIONS OF THE STUDY}

\subsection{Theoretical and management implications}

After carrying out a literature review, having as aim to find studies about social networks and their interactions with the marketing processes, a possibility was found to try to identify the factors and variables that could have some influence on the intention to use social networks to make a purchase. Although the model proposed by Okazaki et al. (2012), with its main constructs and relations between them is adapted and extended. Two cause and effect relationships are included. One of them is part of what is indicated by the Theory of Reasoned Action (influence of social pressure on the intention to have a determined behavior), which highly enriches the model of the authors, and is taken as reference in the analysis of the influence of social networks, expanding even further its field of study. 


\subsection{Discussion}

When adapting and extending the social networking model proposed by Okazaki et al. (2012), problems with its convergence were presented, and to solve this situation, certain indicators of the constructs had to be eliminated in order to have standardized factor loads that contributed to maintain the average for all constructs above 0.7 , according to the reference value found in the literature. During the evaluations of the statistics corresponding to the Bartlett's test and the KMO measure, it was possible to verify a correct adaptation of the model to the sample, thus allowed the further progress towards the understanding of the factor that influence the use of social networks for purchasing decisions.

Furthermore, the model validation via discriminant analysis ensured that valid measures were obtained, since the ones corresponding to the same construct presented a high correlation between them, being these higher than other measurements of constructs. In addition, through the evaluation of Cronbach's alpha, it was possible to verify the high reliability of the internal consistency of the measurement scale.

Once the correct fit of the model to the sample and the internal consistency of the measurement scale were verified, a confirmatory factor analysis was carried out, for the constructs that had at least two indicators with the purpose of identifying to what extent these indicators were reflecting the associated construct. Thus, some correlations between residuals of several indicators were added to finally implement the adjustment methodology of the model through structural equations. The results finally indicated that the model initially proposed with some modifications, allows obtaining a knowledge approximation of the factors that may have some influence on the intention to use social networks to make purchases by university students.

\subsection{Limitations of the study and future outlines}

The previous results show the model adequacy to the sample and the reliability of the internal consistency of the instrument estimated by Cronbach's alpha, which justifies the factorial analysis with the aim of finding the factors that guide and motivate the use of social networks in purchasing decisions. However, it should be noted that at the time of the respective confirmatory factor analyze for each of the constructs, the obtained results are limited and do not contribute to the overall model adjustment.

Despite the difficulties pointed out above, the evaluation of the overall model adjustment, allowed to conclude that it can serve as a basis in the task of identifying the factors that may have some influence on the intention to use social networks to make a purchase, taking the model proposed by Okazaki et al. (2012) as a reference, to which the relationship between the social pressure and intention to use social networks to buy constructs were included based on what is exposed by the Theory of Reasoned Action. This is useful to further expand the theoretical debate and continue to address future studies that evaluate the influence of social networks on different marketing processes, such as the buying and selling relationships of Web pages or social networks. 


\subsection{Implications and recommendations for companies}

The presented findings in the present study support the research antecedents reported in the literature review, confirming the strong influence of the word-of-mouth channel for information transmission about a certain product or service, opening up the possibility of exploiting this information channel to create a competitive advantage due to its low costs, massive access, and ease of penetration in the target audience. This should motivate companies to contemplate new mechanisms and strategies that allow them defining alternative approaches in the advertising of their products in social networks. These strategies should be based on the fact that the surveyed population is very open to receive the contributions or opinions of their peers (friends, acquaintances or other consumers) to make purchasing decisions.

After observing the growing acceptance of marketing in social networks and the influence that such information has on consumer purchasing decisions, it is recommended that companies have more effort to studying what is happening around this phenomenon, and to establish how this marketing tool is able to revitalize the relationship between customers and brands. Consumer behavior could be shaped towards a more accessible attitude to the purchase through the use of social networks. It is worth studying the impact on the implementation of higher levels of transparency in the information transmission, which can generate greater target audience confidence towards the advertising that companies provide in social networks. Likewise, it is recommended to companies that wish to promote their products through social networks, seek alternative strategies that incorporate transparency in information, and stimulate word-of-mouth communication among users, generating a greater impact on the purchase decisions of customers.

\section{REFERENCES}

Abascal, E. and Esteban, I.G., 2005. Análisis de encuestas. Madrid: ESIC Editorial.

Acar, A.S. and Polonsky, M., 2007. Online social networks and insights into marketing communications. Journal of Internet Commerce, 6(4), 55-72.

Ajzen, I., 1991. The theory of planned behavior. Organizational behavior and human decision processes, 50 (2), 179-211.

Akar, E. and Topçu, B., 2011. An examination of the factors influencing consumers' attitudes toward social media marketing. Journal of Internet Commerce, 10 (1), 35-67.

Alvarado, P.A., 2012. Impacto de las redes sociales sobre las variables de decisiones de los agentes. Universidad Nacional de Colombia, Facultad de Ciencias Económicas, Colombia. Available at: http://www.fce.unal.edu.co/wiki/images/0/04/Impacto_de_ las_redes_sociales

_en_las_decisiones_de_los_agentes.pdf. [Accessed: 20 December 2014].

Anderson, J.C. and Gerbing, D.W., 1988. Structural equation modeling in practice: A review and recommended two-step approach. Psychological bulletin, 103 (3), 411-423.

Arcos, V.A., Gutiérrez, S.S.M. and Hernanz, R.J.P., 2014. La aplicación empresarial del marketing viral y el efecto boca-oreja electrónico: opiniones de las empresas. Cuadernos de gestión, 14 (1), 15-31. 
Ajzen, I. and Fishbein, M., 1980. Understanding Attitudes and Predicting Social Behavior. Englewood Cliffs, NJ: Prentice Hall.

Bermudez, J., Chalela, S., Valencia, J. and Valencia, A., 2017. Research Trends in the Study of ICT Based Learning Communities: A Bibliometric Analysis. Eurasia Journal of Mathematics, Science and Technology Education, 13 (5), 1539-1562. DOI: 10.12973/ eurasia.2017.00684a

Bolotaeva, V. and Cata, T., 2010. Marketing opportunities with social networks. Journal of Internet Social Networking and Virtual Communities, 1-8.

Bran, L., Romero, K., Echeverri, L., Peña, J., Vasquez, S., Aguilera, M., Herazo, C. and Valencia, A., 2017. Information and Communication Technologies Influence on Family Relationship. Global Journal of Health Science, 9 (6), 204-213. DOI:10.5539/gjhs. v9n6p204.

Bryant, C.L., Maarouf, S., Burcham, J. and Greer, D., 2016. The examination of a teacher candidate assessment rubric: A confirmatory factor analysis. Teaching and Teacher Education, 57, 79-96.

Brown, J., Broderick, A.J. and Lee, N., 2007. Word of mouth communication within online communities: Conceptualizing the online social network. Journal of interactive marketing, 21 (3), 2-20.

Calvo-Porral, C., Martínez-Fernández, V.A. and Juanatey-Boga, O., 2013. Análisis de dos modelos de ecuaciones estructurales alternativos para medir la intención de compra. Revista Investigación Operacional, 34 (3), 230 - 243.

Cartagena, C., Vasquez, A., Benjumea-Arias, M. and Valencia-Arias, A., 2017. Proposed Model for Measuring Customer Satisfaction with Telecommunications Services. Mediterranean Journal of Social Sciences, 8 (2), 15-26. DOI: 10.5901/mjss.2017.v8n2p15.

Cheung, C.M. and Lee, M.K., 2010. A theoretical model of intentional social action in online social networks. Decision support systems, 49 (1), 24-30.

ComScore, 2013. Futuro Digital Colombia 2013. Available at: http://www.comscore. com/esl/Prensa-y-Eventos/Presentaciones-y-libros-blancos/2014/2014-Digital-Future-in-Focus-Colombia. [Accessed: 12 August 2015].

Davis, F.D., Bagozzi, R. and Warshaw, P., 1989. User acceptance of computer technology: A comparison of two theoretical models. Management Science, 35 (8), 982-1003.

De la Fuente, J. and Justicia, F.J., 2003. Escala de estrategias de aprendizaje ACRA-Abreviada para alumnos universitarios. Electronic journal of research in educational psychology, 1 (2), 139-158.

Dholakia, U.M., Bagozzi, R.P. and Pearo, L.K., 2004. A social influence model of consumer participation in network-and small-group-based virtual communities. International journal of research in marketing, 21 (3), 241-263.

Fishbein, M. and Ajzen, I., 1975. Belief, attitude, intention, and behavior: An introduction to theory and research. Reading, MA: Addison-Wesley.

Frías-Navarro, D., 2013. Alfa de Cronbach y consistencia interna de los ítems de un instrumento de medida. Available at: http://www.uv.es/ friasnav/AlfaCronbach.pdf. [Accessed: 10 May 2015].

Gatautis, R. and Kazakevičiūtè, A., 2012. Consumer behavior in online social networks: review and future research directions. Economics and Management, 17 (4), 1457-1463. 
George, D. and Mallery, M., 2003. Using SPSS for Windows step by step: a simple guide and reference. Boston, MA: Allyn y Bacon.

Hair, J.F., Anderson, R.E., Tatham, R.L. and Black, W.C., 2001. Análisis Multivariante. $5^{\text {a }}$ ed. Madrid: Prentice Hall Iberia.

Hill, S., Provost, F. and Volinsky, C., 2006. Network-based marketing: Identifying likely adopters via consumer networks. Statistical Science, 256-276.

Hoyos, J. and Valencia, A., 2012. El papel de las TIC en el entorno organizacional de las pymes. Trilogía. Ciencia, Tecnología y Sociedad, 7 (1), 105-122.

Hox, J.J. and Bechger, T.M., 1998. An introduction to structural equation modeling. Family Science Rewiew, 11, 354-373.

Hsu, M.H., Ju, T.L., Yen, C.H. and Chang, C.M., 2007. Knowledge sharing behavior in virtual communities: The relationship between trust, self-efficacy, and outcome expectations. International journal of human-computer studies, 65 (2), 153-169.

Hu, L.T. and Bentler, P.M., 1999. Cutoff criteria for fit indexes in covariance structure analysis: Conventional criteria versus new alternatives. Structural equation modeling: a multidisciplinary journal, 6 (1), 1-55.

Kaiser, H.F., 1974. An index of factorial simplicity. Psychometrika, 39 (1), 31-36.

Kalpaklioglu, N.U. and Toros, N., 2011. Viral marketing techniques within online social network. Journal of Yasar University, 24 (6), 4112-4129.

Kaplan, D., 2008. Structural equation modeling: Foundations and extensions. $2^{\mathrm{a}}$ ed. Thousand Oaks: Sage Publications.

Kenny, D.A., Kashy, D.A. and Bolger, N., 1998. Data analysis in social psychology. In: Gilbert, D., Fiske, S. and Lindzey, G, eds. The handbook of social psychology. McGraw-Hill, 233-265.

Kunz, M.B. and Hackworth, B.A., 2011. Are consumers following retailers to social networks? Academy of Marketing Studies Journal, 15 (2), 1-22.

Lévy, J.P., Martín, M.T. and Román, M.V., 2006. Modelización con estructuras de covarianzas en ciencias sociales. España: Gesbiblo, S.L.

Mahler, C., Giesler, M., Stock, C., Krisam, J., Karstens, S., Szecsenyi, J. and Krug, K., 2016. Confirmatory factor analysis of the German Readiness for Interprofessional Learning Scale (RIPLS-D). Journal of interprofessional care, 30 (3), 381-384.

Mangold, W., Faulds, D., 2009. Social media: The new hybrid element of the promotion mix. Business Horizons, 52 (4), 357-365.

Martínez-García, J.A. and Martínez-Caro, L., 2009. La validez discriminante como criterio de evaluación de escalas: ¿teoría o estadística? Universitas Psychologica, 8 (1), 27-36.

Maurer, C. and Wiegmann, R., 2011. Effectiveness of advertising on social network sites: a case study on Facebook. Vienna: Springer.

Miller, R. and Lammas, N., 2010. Social media and its implications for viral marketing. Asia Pacific Public Relations Journal, 11 (1), 1-9.

Okazaki, S., Benito, N.R. and Martínez, S.C., 2012. Antecedentes de las redes sociales como canales de comunicación promocional para los jóvenes. Revista Española de Investigación en Marketing ESIC, 16 (2), 31-48.

Pavia, L., Cavani, P., Di Blasi, M. and Giordano, C., 2016. Smartphone Addiction Inventory (SPAI): Psychometric properties and confirmatory factor analysis. Computers in Human Behavior, 63, 170-178. 
Pookulangara, S. and Koesler, K., 2011. Cultural influence on consumers' usage of social networks and its' impact on online purchase intentions. Journal of Retailing and Consumer Services, 18 (4), 348-354.

Ramírez-Correa, P., 2014. Uso de internet móvil en Chile: explorando los antecedentes de su aceptación a nivel individual. Ingeniare. Revista chilena de ingeniería, 22 (4), 560-566.

Ranaweera, H.M.B.P., 2016. Perspective of trust towards e-government initiatives in Sri Lanka. SpringerPlus, 5 (1), 1-11.

Schlereth, C., Barrot, C., Skiera, B. and Takac, C., 2013. Optimal Product-Sampling Strategies in Social Networks: How Many and Whom to Target? International Journal of Electronic Commerce, 18 (1), 45-72.

Smith, T., Coyle, J.R., Lightfoot, E. and Scott, A., 2007. Reconsidering models of influence: the relationship between consumer social networks and word-of-mouth effectiveness. Journal of Advertising Research, 47 (4), 387-397.

Soares, A.M., Pinho, J.C. and Nobre, H., 2012. From social to marketing interactions: The role of social networks. Journal of Transnational Management, 17 (1), 45-62.

Tanuri, I., 2010. A literature review: Role of social media in contemporary marketing. Available at: https://issuu.com/virginiahall5/docs/a-literature-review-role-of-social. [Accessed: 10 January 2012].

Uriel, E. and Manzano, J.A., 2002. Análisis multivariante aplicado. Madrid: Paraninfo.

Uribe, F., Rialp, J. and Llonch, J., 2013. El uso de las redes sociales digitales como herramienta de marketing en el desempeño empresarial. Cuadernos de Administración, 26 (47), 205-231.

Wang, J.C. and Chang, C.H., 2013. How online social ties and product-related risks influence purchase intentions: A Facebook experiment. Electronic Commerce Research and Applications, 12 (5), 337-346.

Valencia, A., Benjumea, M. and Rodríguez-Lora, V., 2014. Intención de uso del e-learning en el programa de Administración Tecnológica desde la perspectiva del modelo de aceptación tecnológica. Revista Electrónica Educare, 18 (2), 247-264. DOI: 10.15359/ ree.18-2.13.

Valencia, A., González, G. and Castañeda, M., 2016. Structural equation model for studying the mobile-learning acceptance. IEEE Latin America Transactions, 14 (4), 19881992. DOI: 10.1109/TLA.2016.7483544.

Valencia, A., Salazar, O. and Ovalle, D., 2013. Improving the Entrepreneur's Market Research Strategies Learning Process Using the MaREMAS Environment. In J. M. Corchado et al., eds. Highlights on Practical Applications of Agents and Multi-Agent Systems: International Workshops of PAAMS 2013, Salamanca, Spain, May 22-24, 2013. Proceedings. Berlin, Heidelberg: Springer Berlin Heidelberg, pp. 363-374. Available at: https://doi.org/10.1007/978-3-642-38061-7_34.

Welch, S. and Comer, J., 1988. Quantitative methods for public administration: Techniques and applications. $2^{\mathrm{a}}$ ed. Fort Worth: Harcourt Brace College Publishers. 
